\title{
Analisis Efektivitas G20 Dalam Menangani Krisis Finansial Tahun 2008
}

\section{Arum Tri Utami ${ }^{1}$}

\begin{abstract}
Abstrak
Krisis finansial 2008 menjadi sebuah permasalahan yang sulit dan menantang untuk diselesaikan, yang membawa pada pentingnya reformasi artsitektur tata kelola ekonomi global. G20 muncul sebagai sebuah tata kelola ekonomi global yang signfikan. Kedua puluh negara anggota G20 dapat mengambil peran yang signifikan dalam ekonomi global. Berbagai upaya dikeluarkan oleh G20 dalam menyelesaikan krisis finansial 2008. Salah satu upayanya adalah dengan pemberian stimulus fiskal sebesar 2\% dari PDB negara anggota G20. Kebijakan lainnya terus didorong oleh G20 untuk membuat aturan dan pengawasan yang efektif serta berbagai kebijakan sektor finansial lainnya. Efektivitas G20 dalam menyelesaikan krisis finansial G20 menjadi penting untuk dianalisa untuk membuat tata kelola ekonomi global yang lebih baik.
\end{abstract}

\section{Kata-Kata Kunci : G20, krisis finansial 2008, efektivitas, KTT G20}

\begin{abstract}
Financial crisis 2008 posed a serious of deeper and more challenging problem, that led to calls for urgent reform of the architecture of global economic governance. G20 emerged as a significant global economic governance. The twenty members of G20 can take a significant role in economic global. Various efforts were made by G20 through policies resulted from the Summit. Those efforts include providing fiscal stimulus in the amount of 2\% from GDP the member of G20. Other policies have been pushed by G20 to make an effective regulatory, supervisory and other financial sector policies. The effectiveness of G20 in handling financial crisis 2008 was important to be analyzed to make a global economic governance will be better.
\end{abstract}

Keywords : G20, financial crisis 2008, effectiveness, G20's summit.

\section{Pendahuluan}

Krisis yang terjadi di Asia pada tahun 1997an merupakan sebuah krisis yang dampaknya meluas secara global. Hal ini yang menjadi latar belakang lahirnya forum G20 (YP, 2010). Forum G20 didirikan pada September 1999, dimana para menteri keuangan dan gubernur Bank Sentral G7 ingin adanya perluasan dialogi khususnya mengenai isu ekonomi, yang kemudian memprakarsai terbentuknya The Group of Twenty Finance Ministers and Central Bank Governors (G20) (YP, 2010). Anggota dari G20 adalah 19 negara anggota (Argentina, Australia, Brazil, Kanada, Republik Rakyat Tiongkok (RRT), Prancis, Jerman, India, Indonesia, Italia, Jepang, Korea Selatan, Meksiko, Rusia, Saudi
Arabia, Afrika Selatan, Turki, Inggris, Amerika Serikat) dan Uni Eropa. Tujuan utama pembentukan G20 adalah menyediakan suatu forum diskusi permanen yang intensif bagi para pembuat kebijakan keuangan dalam rangka menciptakan stabilitas keuangan global melalui upaya pencegahan dan penyelesaian krisis keuangan internasional (Pusat Kebijakan Pembiayaan Perubahan Iklim dan Multilateral (Badan Kebijakan Fiskal Kementerian Keuangan, 2012).

Forum intergovernmental ini mulai dikenal pada tahun 2008 ketika dirubah menjadi pertemuan kepala negara/kepala pemerintah agar mendapat bobot keputusan politik yang lebih baik (Wright, 2012). Transformasi tersebut dilatar belakangi dari

\footnotetext{
${ }^{1}$ Alumni S1 HI, FISIP, Universitas Jenderal Soedirman dan Mahasiswa S2 Jurusan Hubungan Internasional, FISIP, Universitas GadjahMada.
} 
kondisi krisis keuangan yang berkepanjangan di Amerika Serikat yang mana mulai memberikan dampak pada kestabilan perekonomian negara lainnya yang memiliki keterkaitan ekonomi secara langsung maupun tidak langsung (G20 Summit 2009 Pitsburgh ). Sehingga ketika dirubah menjadi forum pertemuan antar kepala negara dapat meningkatkan komitmen dari negara anggotanya.

Krisis 2008 merupakan sebuah krisis subprime mortage yang diawali di Amerika Serikat dan meluas secara global terutama di Uni Eropa dan negara maju lainnya. Perlu diketahui, kredit subprime mortage adalah pinjaman yang diberikan kepada peminjam dengan syarat yang tidak begitu ketat. Kredit ini adalah pinjaman yang beresiko baik untuk kreditur (yang meminjamkan) dan debitur (peminjam), khususnya dibidang perumahan. Krisis tersebut membawa implikasi pada ekonomi global karena yang terkena krisis adalah negara dengan kekuatan ekonomi terbesar didunia, Amerika Serikat. Krisis yang dianggap unik karena terjadi di Amerika Serikat sebagai negara pusat kapitalisme global dengan perdagangan bebas sebagai basis ekonominya. Hampir semua negara di dunia memiliki kerjasama ekonomi dan perdagangan dengan Amerika Serikat, sehingga krisis yang terjadi meluas dengan cepat (Jerrefy \& Spero, 2010).

Krisis 2008 yang merupakan krisis di negara maju,yang membuat peran G20 menjadi semakin signifikan karena negara maju membutuhkan bantuan likuiditas dari emerging market dan negara berkembang. Sebagai sebuah media pertemuan antara negara maju dan berkembang, G20 membuat adanya komitmen pada KTT Washington, London, Pittsburgh yaitu dengan melaksanakan kebijakan stimulus fiskal dari 2\% PDB, melakukan rekapitalisasi perbankan dan restrukturisasi aset yang bermasalah dengan biaya sebesar US\$ 2-5 triliun, sumber dari IMF sebesar US\$ 500 miliar dan alokasi untuk menambahkan likuiditas sebanyak \$250 miliar. Tidak hanya sampai disitu saja, pada tahun 2012, KTT di Los Cabos Mexico, G20 sepakat untuk menambahkan dana talangan melalui Dana Moneter IMF sebanyak US\$ 430 miliyar. Serta meminta kepada anggotanya untuk melakukan komitmen kebijakan stimulus fiskal sebanyak 3\% dari PDB (Heywood, 2011, p. 476).

Berbagai upaya telah dilakukan oleh G20 dalam penanganan krisis 2008, karena negara anggota berpendapat jika semua negara anggota dapat melakukan kebijakan dari KTT G20 maka akan berdampak signifkan bagi ekonomi global, serta akan diikuti oleh negara lain didunia. Upaya ini kemudian mengundang sebuah pertanyaan baru, apakah upaya yang dilakukan oleh G20 itu efektif atau tidak dalam menangani krisis tahun 2008, mengingat G20 hanya sebuah forum yang setiap tahunnya melakukan Konferensi Tingkat Tinggi secara rutin. 


\section{Landasan Teori}

Efektivitas Rezim

Berbagai permasalahan yang terjadi di dunia internasional, membuat peran rezim internasional semakin meningkat. Rezim internasional penting karena dapat mempengaruhi perilaku negara. Krasner berpendapat rezim adalah prinsip, norma, aturan, dan prosedur pengambilan keputusan dimana aktornya berkumpul dan berharap pada suatu isu tertentu. Sedangkan Keohane dan Nye menyatakan bahwa rezin adalah seperangkat aturan tata kelola. G20 sendiri merupakan sebuah rezim dimana tidak memiliki institusi atau kantor yang tetap. Adanya pertemuan setiap tahun antar anggotanya. Walaupun tidak legally binding (mengikat secara hukum), tetapi G20 menghasilkan adanya prinsip, norma dan aturan serta adanya prosedur pembuatan kebijakan (Heywood, 2011).

Sebagai sebuah rezim internasional dengan adanya aturan yang dibuat, maka dibutuhkan adanya ukuran atau penilaian terhadap efektivitas sebuah rezim internasional. Dalam mengukur efektivitas sebuah rezim, maka terdapat beberapa komponen penilaiannya (Miles, 2002) :

\section{A. Output}

Komponen pertama adalah dengan melihat hasil keluaran dari sebuah rezim internasional. apakah bersifat tertulis atau tidak tertulis. Misalnya saja sebuah rezim internasional apakah menghasilkan deklarasi, treaty, atau norma.

\section{B. Outcome}

Outcome adalah sebuah komponen dengan menilai bagaimana perubahan perilaku dari negara anggota sebuah rezim internasional. institusi atau rezim yang efektif jika membuat adanya perubahan tingkah laku dari pesertanya.

\section{Impact}

Perubahan tingkah laku dari sebuah rezim akan membuat adanya sesuatu yang telah dirancang oleh sebuah institusi atau rezim. Sebuah rezim tentunya memiliki tujuan, apakah perubahan perilaku tersebut dapat mewujudkan tujuan yang hendak dicapai atau tidak.

Output yang dimaksudkan adalah bagaimana negara anggota dari sebuah rezim dalam mengimplementasikan aturan dalam rezim tersebut, bagaimana proses monitoringnya, apakah mengikat atau tidak. Mengikat atau tidaknya ditentukan dari bentuk aturan yang dikeluarkan pada saat pertemuan rutin dari rezim tersebut. problem malignancy adalah sebuah rezim yang sulit karena ketika negara tidak mau bekerjasama secara politis. Hal ini biasanya dikarenakan tidak semua negara merasakan hal tersebut sebagai masalahan dan belum ada penyelesaiannya. Sebuah masalah semakin bersifat maglinancy 
maka kerjasama yang efektif akan semakin sulit untuk dilakukan (Miles, 2002, p. 5).

\section{Gambar.1 Object Assessment}

Sumber : (Edward, Miles. et.al., 2002).

G20 adalah sebuah rezim dengan output seperti deklarasi dan communique yang sifatnya tidak mengikat, sehingga implementasinya dikembalikan kepada masing

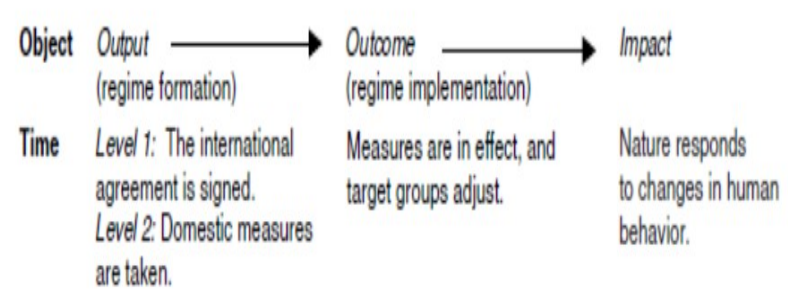

-masing negara anggota. Negara anggota G-20 berkomitmen untuk terlebih dahulu melaksanakan komitmen-komitmennya sebelum meminta negara lain melakukannya (leading by example) (Djumala, 2010). Sehingga komitmen dari masing-masing anggota G20 dibutuhkan untuk menjalankan semua aturan dan kebijakan yang telah dibuat. Komitmen ini yang kemudian nantinya diimplementasikan dalam bentuk kebijakan nasional suatu negara.

\section{Krisis Tahun 2008}

Krisis ekonomi yang terjadi di Amerika Serikat disebabkan tidak adanya regulasi yang mengatur mengenai pasar saham sehingga pasar modal AS menjadi sangat bebas dan mengakibatkan adanaya gelombang krisis gagal bayar di Amerika Serikat. Pada tahun 2007 dan 2008, hancurnya pasar morage- backed securities membawa adanya krisis finansial dengan jatuhnya bank investasi besar di Amerika Serikat (Bear Stearns) yang berakibat pada institusi finansial AS dan Uni Eropa dan pembekuan pasar kredit global. Krisis ini berasal dari Amerika Serikat dengan adanya asset bubble yang berefek pada banyak hal yang saling terkait. Suku bunga renda dan pinjaman yang berlebihan di Amerika Serikat dengan mudahnya praktek pinjaman dalam pembelian rumah (Heywood , 2011, p. 59).

Kredit dan pinjaman lemah pada mortage (perumahan) di AS membuat resiko yang berlebihan pada institusi finansial. Pinjaman untuk perumahan ini membuat adanya kemungkinan baru dengan instrumen kredit dari bank subprime mortage yang kemudian diperjaul belikan secara global. Banyak institusi dan investor dari neagara lain yang membeli instrumen mortage-backedfinance ini. Masalah terjadi ketika orang yang kredit rumah tersebut tidak dapat membayar. Kemudian adanya efek domino yang terjadi, debitur atau pihak yang kredit rumah tidak bisa membayar, maka akan membuat institusi subprime mortage juga dirugikan, dan akan berdampak pada mereka yang menanamkan invetasinya di bidang tersebut. adanya konsekuensi yang sistematik dan mengglobal. Lemaga keuangan kehilangan kepercayaan dari pasar internasional. Krisis mengancam ekonomi riil sebagai lembaga keuangan. Amerika Serikat sebagai negara dengan kekuatan ekonomi yang paling besar membuat dampak krisis di negara tersebut meluas 
dengan cepat terutama ke Uni Eropa (Finance Detik, 2009).

Krisis ekonomi dan keuangan global tidak saja mempengaruhi kondisi perekonomian di negara maju, seperti AS atau negara-negara di kawasan Eropa, namun juga mulai berdampak kepada negara-negara kawasan lain di dunia, termasuk banyak negara di Asia. Krisis AS dan Eropa pada 2008-2009 sebagai puncak peristiwa yang mengubah konstelasi ekonomi global. Banyak negara sampai saat ini masih berkutat pada upaya pemulihan ekonominya masing-masing (CNN Indonesia, 2016).

\section{Upaya G20 dalam Menangani Krisis 2008}

Pada saat krisis 2008 terjadi G20 melihat bahwa tidak hanya sebagai krisis sistem keuangan global tetapi juga krisis yang lebih luas dengan adanya krisis output riil serta lapangan kerja global yang membutuhkan adanya penanganan komprehensif dan lebih luas. G20 untuk menangani krisis ini tidak hanya dari segi stabilisasi sistem keuangan tetapi juga upaya dalam mengatasi resesi ekonomi yang terjadi untuk dapat mengembalikan tingkat pertumbuhan global. Melihat dari greet depression 1930an, G20 melihat dibutuhkannya langkah bersama untuk menerapkan kebijakan stimulus fiskal, tidak hanya dalam rangka stabilisasi pasar tetapi juga mendorong aktivitas ekonomi riil (Pusat Kebijakan Pembiayaan Perubahan Iklim dan Multilateral Badan Kebijakan Fiskal Kementerian Keuangan, 2012, p. 10).
Dalam mengatasi krisis 2008, menteri keuangan dan gubernur bank sentral G20 mengadakan pertemuan di San Paulo, Brasil pada 7-8 November 2008, dan kepala negara anggota G20 mengadakan Konferensi Tingkat Tinggi (G20 summit) di Washington DC pada 15 November 2008. Pertemuan tersebut menghasilakn Deklarasi Para Pemimpin G20 dengan isinya adalah rekomendasi principles dan action plan G20 dalam rangka penanganan krisis yang terdiri dari rencana jangka pendek dan langkah jangka menengah. Dalam deklarasi tersebut prinsip utama dalam mengatasi krisis adalah (Pusat Kebijakan Pembiayaan Perubahan Iklim dan Multilateral Badan Kebijakan Fiskal Kementerian Keuangan, 2012, p. 30) :

A. Penerapan prinsip respon makro terhadap krisis dan koordinasi kebijakan makro G20.

Krisis 2008 yang diawali dari memburuknya balance sheet sektor perbankan Amerika Serikat yang diakibatkan oleh kejatuhan subprime mortage menyebabkan masalah likuiditas yang menyebar ke seluruh dunia membuat adanya global repricing of risk. Hal tersebut membuat adanya credit crunch yang berakibat pada memburuknya ekonomi di berbagai negara. G20 melihat dibutuhkannya respon makro melalui stimulus fiskal yang didorong dengan kebijakan moneter sesuai dengan kondisi masing-masing negara untuk dapat melakukan stabilisasi sistem keuangan melalui adanya rekapitalisasi dan perbaikan 
balance sheet institusi keuangan, dan adanya injeksi likuiditas untuk mengembalikan kemampuan intermediari. Agar efektif maka dibutuhkan untuk dilakukan secara serempak oleh seluruh anggota G20 serta jumlahnya harus signifikan.

B. Peningkatan standar regulasi sistem keuangan

Krisis 2008 yang diakibatkan oleh banyaknya ketersediaan dana murah yang menodorong investasi produk keuangan. Hal tersebut mendorong G20 untuk mengkaji dan menyelaraskan standar akunting global dengan tujuan memperkuat rezim perundangan, prudential oversight, dan pengelolaan resiko yang sesuai dengan standar internasional. Rencana jangka pendeknya, G20 fokus pada upaya memperkuat resiliensi serta transparansi pasar kredit derivatif dan mengurangi sistemiknya. G20 mendorong adanya assessment yang lebih transparan terhadap sistem perundangan nasional khususnya di negara yang menjadi financial center.

C. Peningkatan transparansi dan akuntabilitas sistem keuangan global G20 melihat bahwa untuk menjaga stabilitas sistem keuangan ketika adanya gejolak dan ketidakpercayaan dari masyarakat, diperlukan adanya inisiatif untuk melakukan disclosure secara menyeleuruh dan akurat terhadap produk keuangan dan kondisi keuangan perusahaan. Selain itu G20 juga mentargetkan adanya definisi yang mencakup institusi keuangan yang dianggap paling penting secara sistemik, dan menentukan regulasi yang memadai khususnya terkait dengan transparansi dan akuntabilitas mereka dengan tujuannya adalah agar institusi sistemik tersebut lebih bertanggung jawab dalam pengelolaannya.

D. Penguatan integrasi pasar keuangan global

Peningkatan perlindungan bagi investor dan nasabah, pencegahan conflict of interest di sistem keuangan, manipulasi pasar dan kegiatan ilegal. Untuk melakukan hal tersebut, G20 mendorong mekanisme kerjasama untuk meningkatkan sharing informasi khususnya dalam hal transparansi dan pengelolaan prinsip kerahasiaan perbankan secara lebih bertanggung jawab.

E. Penguatan kerjasama internasional dalam aktivitas keuangan lintas batas

Negara anggota G20 diikutsertakan dalam governance sistem keuangan global yaitu pada Financial Stability Board Forum (yang kemudian disebut sebagai Financial Stability Board) dan standard setting lainnya.

KTT Washington diadakan 14-15 November 2008. Dalam KTT ini dihasilkan suatu deklarasi bersama kepala negara anggota G20 berisi berbagai komitmen. Komitmenkomitmen tersebut diantaranya adalah langkah -langkah reformasi ekonomi global agar krisis tidak terjadi lagi, penguatan perdagangan internasional yang terbuka, inovasi pada sektor ekonomi untuk mendorong pertumbuhan ekonomi, dan penanggulangan kemiskinan. 
ekonomi untuk mendorong pertumbuhan ekonomi, dan penanggulangan kemiskinan.

Negara anggota G20 sepakat untuk mengambil langkah kuat dan signifikan untuk merangsang perekonomian global dengan cara menyediakan likuiditas, penguatan modal dari lembaga keuangan, melindungi tabungan, memastikan bahwa International Financial Institution (IF Is) dapat memberikan dukungan penuh pada ekonomi global. Membantu negara maju dan berkembang dalam dalam mendapatkan akses melalui fasilitas likuiditas dan kegiatan pendukung. Mendorong Bank Dunia dan MDBs dalam mendukung rencana pembangunan. Memastikan Bank Dunia, IMF dan MDBs memiliki sumber daya yang cukup guna melanjutkan peran mereka dalam penanganan krisis. Didalam deklarasi ini juga ada langkah jangka pendek dan jangka menengah dalam penanganan dampak akibat krisis 2008 (Declaration of the Summit on Financial Market and the World Economy, 2008).

Komitmen yang dihasilkan pada KTT London pada tanggal 1-2 April 2009 (G20 London Summit ) :

- Meningkatkan sumber daya Bank Dunia, IMF dan MDBs tiga kali lipat yang kemudian dana tersebut dipakai untuk membantu negara yang paling lemah perekonomiannya

- Melakukan ekspansi fiskal dengan cara menyediakan jutaan lapangan pekerejaan baru

- Bank Sentral melakukan pemotongan tingkat suku bunga dengan menggunakan kebijakan moneter untuk menstabilkan harga

- Langkah jangka panjang dengan menjaga kesinambungan fiskal dengan menjaga pertumbuhan ekonomi. Kemudian secara rutin melaporkannya untuk dievaluasi oleh IMF.

G-20 merupakan salah satu institusi global yang mengambil peran dalam hal ini di samping IMF melalui kebijakannya dalam mengatasi trade finance shortage dengan memberikan kredit sebesar \$250 miliar. Kedua, negara-negara perlu untuk melakukan sumber demand yang tidak hanya berasal dari ekspor seperti pasar domestik dan regional (Cattaneo, 2010, p. 50). Upaya tersebut dilakukan untuk mencari solusi bagi negara berkembang. Jumlah pengangguran diperkirakan meningkat lebih dari 30 juta pada tahun 2009 dengan total 200 juta (Cattaneo , 2010, p. 59). Solusi ini didukung dengan menciptakan lapangan pekerjaan baru di negara-negara berkembang oleh G-20 dan institusi global lain serta perbaikan infrastruktur. Ketiga, menekan proteksi untuk menghidupkan pasar kembali (Cattaneo , 2010, p. 61).

KTT Pittsburgh yang diadakan pada 24 -25 September 2009 merupakan kelanjutan dari pertemuan sebelumnya. Selama proses perbaikan terus berjalan dibentuk sebuah tujuan baru untuk abad 21 yaitu pertumbuhan ekonomi yang kuat, berkelanjutan, dan berimbang yang kemudian terangkum dalam 
Framework for Strong, Sustainable and Balanced Growth. FSSBG ini adalah langkah bersama untuk menilai bagaimana kebijakan negara anggota tepat atau tidak, dan menilai apakah tindakan mereka secara kolektif dapat konsisten untuk memenuhi tujuan bersama. Komitmen yang disetujui adalah dengan menerapkan standar internasional guna menghindari pengambilan resiko yang berakibat pada perekonomian global. Dalam deklarasi tersebut juga disebutkan bahwa menetapkan G20 sebagai forum utama dalam kerjasama ekonomi internasional. Mengenalkan adanya Financial Stability Board (FSB) dengan negara emerging di dalamnya serta untuk mengkoordinasi dan memonitor perkembangan dari perekonomian negaranegara tersebut. Meningkatkan suara negara berkembang dalam IMF (G20 Summit 2009 Pitsburgh ).

\section{Efektivitas G20 dalam Menangani Krisis 2008}

G20 sebagai sebuah forum antara negara maju dan berkembang, membuat komitmen yang dihasilkan oleh G20 menjadi sulit untuk dilakukan, karena banyaknya kepentingan diantara anggotanya. Upaya yang dilakukan G20 dalam menangani krisis finansial 2008 juga menghadapi tantangan yang serupa. Penanganan krisis yang merupakan permasalahan malign yang sulit untuk dipecahkan dan diselesaikan. Berbagai Collective action yang dilakukan oleh G20 dalam menyelesaikan krisis finansial telah dihasilkan dari berbagai pertemuan yang memang diadakan untuk membahas penanganan krisis 2008. Tetapi collective action tersebut telah membuat masalah baru yaitu dengan adanya free rider, hal ini dikarenakan semangat untuk menyelesaikan krisis finansial tidak diimbangi dengan semangat dari setiap anggotanya karena setiap anggota G20 memiliki kepentingan nasional masing-masing yang bertentangan dengan agenda yang hendak dijalankan oleh G20 (Manhoman \& Samanta, 2014).

Pada awal krisis terjadi G20 membuat adanya agenda stimulus fiskal. Pada KTT Pittsburgh, 24-25 September 2009 agenda stimulus fiskal tersebut dijadikan sebagai agenda utama, serta menjadi acuan dari kebijakan domestik negara anggota G20. Negara anggota G20 menyediakan stimulus fiskal sebagai pengembangan dari Framework for Strong, Sustainable and Balanced Growth (FSSBG) yang ada pada G20. Ada dua kondisi yang saling bertentangan, dimana negara maju membutuhkan pembiayaan untuk menutupi defisitnya. Sedangkan negara emerging market seperti China mendapatkan kepercayaan lebih dari investor karena kondisi ekonomi mereka yang lebih stabil. Efektivitas dari G20 terhambat dalam menangani krisis 2008 dipengaruhi oleh emerging marekat ini. Tetapi likuiditas yang masuk ke emerging market juga harus mendapatkan perhatian lebih. Sehingga IMF mengeluarkan aturan mengenai core and non core liquidity indicators bagi 
masing-masing negara. Indikator tersebut berguna dalam memonitor untuk dijadikan ukuran vulnerabilitas perekonomian dari sebuah negara. Menanggapi usulan yang diajukan oleh IMF, sebagian besar neagara anggota G20 menyetujui dan mendukung hal tersebut. Tetapi tidak semua negara memiliki reaksi positif dan antusiasme yang tinggi terhadap usulan indikator oleh IMF (Manhoman \& Samanta, 2014).

Negara emerging market dan berkembang menganggap indikator tersebut tidak dapat menggambarkan secara akurat mengenai kondisi likuiditas, dimana setiap neagra memiliki karakter yang berbeda. Negara berkembang menuntut adanya kemandirian likuiditas tanpa adanya kewajiban untuk tunduk pada aturan dari IMF dan instutusi keuangan lainnya. berbagai aturan dalam G20 yang berkaitan tentang global liquidity management tidak dijalankan oleh negara emerging market dan berkembang. Sedangkan negara maju sangat mendorong fungsi IMF yang lebih besar dalam pengawasan likuiditas internasional. Negara berkembang beranggapan jika IMF terlibat terlalu banyak maka akan membatasi keluwesan dari negara berkembang dalam perekonomiannya (Vines, 2010, p. 157).

Sebuah rezim dapat dikatakan efektif jika menghasilkan adanya outcome, perubahan tingkah laku dari negara anggotanya. Efektivitas G20 menjadi karena msih pada level komitmen belum pada tataran aplikatif.
Hal ini dapat dilihat dari tidak adanya kontrol yang memadai paska komitmen tersebut dibuat. Sehingga negara anggota kebanyakan lebih memilih unutk menjalankan kepentingan nasionalnya. FSB yang dibuat oleh G20 memiliki tujuan yang ambisius karena ingin adanya identifikasi ancaman krisis dan mengembangkan pengawasan serta regulasi untuk dapat memonitor implementasi dari keputusan pertemuan G20. Pemenuhan komitmen dari negara anggota untuk output (aturan yang dibuat oleh G20) menjadi kunci utama keberhasilan G20 dalam menangani krisis 2008. G20 sendiri hakikatnya memberikan peran sentral kepada negara anggota untuk sebagai inisiator komitmen, pelaksan komitmen dan penanggung jawab pelaksana. Kemudian negara melaporkan dengan sukarela pelaksanaan dari komitmen tersebut. mekanisme seperti ini disebut sebagai Mutual Assessment Process (MAP) yang digunakan dalam G20 (Vines, 2010, p. 159).

Sejak tahun 2008, Research Group University of Toronto melakukan penelitian terhadap komitmen yang dijalankan oleh negara anggota G20. Penilaian didasarkan pada informasi publik yang tersedia, dokumentasi serta laporan media. Pelaporan akuntabilitas adalah salah satu bentuk transparansi. Research Group ini memantau 53 komitmen dari neagra anggota G20 semenjak KTT G20 pada tahun 2008. Skor 1 diberikan kepada negara anggota yang kepatuhannya penuh, 0 untuk negara yang sebagian 
mematuhi komitmen atau perkerjaannya sedang berjalan, -1 diberikan kepada negara yang tidak patuh (G20 members compliance ).

\section{Dalam hasil penelitian G20 Research} Group (2015), tidak semua negara menjalankan komitmen yang telah disepakati pada saat KTT. Misalnya dalam KTT Washington 2008 dan Pittsburgh 2009 sebagai sebuah pertemuan yang mengutamakan penyelesaian krisis, yang mendapatkan penilaian positif dan satu kebanyakan dari negara maju karena krisis yang mereka alami sehingga mereka yang menganggap komitmen dari G20 penting untuk dilakukan. Sedangkan untuk negara berkembang dan emerging market. Misalnya untuk China pada pertemuan Washington nilainya 0 dan pada pertemuan London nilainya (-). Dengan melihat hal tersebut maka Efektivitas G20 dalam menangani krisis 2008 dianggap masih pada tataran great yaitu important (masalah yang ditangani adalah masalah penting berupa krisis finansial) but still imperfect (masih ada beberapa negara anggota yang tidak menjalankan komitmen). Dan melihat impact yang dihasilkan berupa keadaan ekonomi di negara yang terkena krisis, Amerika Serikat dan Uni Eropa, yang sudah membaik.

\section{Kesimpulan}

Forum G20 sebagai sebuah forum yang mempertemukan kepenringan antara negara maju dan berkembang dianggap sebagai forum yang signifikan terutama setelah adanya krisis finansial 2008 yang awalnya bermula di Amerika Serikat meluas dengan cepat terutama di Uni Eropa. Berbagai komitmen (output) dikeluarkan oleh G20 untuk menyelesaikan krisis tersebut. Komitmen yang dihasilkan sifatnya tidak mengikat tetapi dikembalikan kepada masing-masing negara anggota. Efektivitas G20 dalam menangani krisis 2008 dianggap masih pada tataran great yaitu important (masalah yang ditangani adalah masalah penting berupa krisis finansial) but still imperfect (masih ada beberapa negara anggota yang tidak menjalankan komitmen). Dan melihat impact yang dihasilkan berupa keadaan ekonomi di negara yang terkena krisis, Amerika Serikat dan Uni Eropa, yang sudah membaik. 


\section{Daftar Pustaka}

\section{Buku dan Jurnal}

Agarwal, Manhoman dan Sayan Samanta. 2014. Financial Crisis of 2008 and Shifting Economic. Washington : Sage Publication

A Jeffery dan Joan. E Spero, The Politics of International Economic Relations. 2010. Canada : Wadsworth Cengage Learning.

David Shorr dan Thomas Wright.The G20 and Global Tata kelola : An Exchange; dalam Routledge dkk; Survival : Global Politics and Strategy

Djumala, Darmansyah.2010. G20 dan Diplomasi Indonesia. Jurnal Diplomasi (Membangun Ekonomi dengan Diplomasi Ekonomi Kementerian Luar Negeri .vol.2 No.2 Juni 2010

Edward, Miles et.al. 2002. Environmental Regime Effectiveness :Confronting Theory with Evidence. London : The MIT Press

Fues, Thomas and Wolf, Peter . G-20 and Global Development. Bonn: DIE.

Hermawan, YP. (2010). Formalizing the G20 outreaching contact groups and Civil G20, in Hartt Heywood, Andrew, Global Politics, Palgrave Foundations, Londond, 2011

Oliver Cattaneo et al. 2010. Global Value Chains in A Postcrisis World: A Development Perspective Washington DC: The World Bank

Pusat Kebijakan Pembiayaan Perubahan Iklim dan Multilateral Badan Kebijakan Fiskal Kementerian Keuangan RI .2012. G20, Ekonomi Global, dan Peranan Indonesia. Jakarta:Kementerian Keuangan RI

Vines, David. 2010. The Global Macroeconomic Crisis and G20 Macroeconomic Policy Coordination. Washington : Saga Publication

Zamroni, Salim.2011.Indonesia in the G20 : Benefits and Challange Amidst National Interest and Priorities. Wilhelm, Homfmeister et.al .G20 Percepttion and Perspective for Global Tata kelola. Singapore : Koard-Adnauer-Stiftung.

Sumber Internet

G20 summit 2009 Pittsburgh diakses di https://www.g20.org/about_g20/ past summits/2009 pittsburgh

Declaration of the Summit on Financial Markets and the World Economy, Washington Summit diakses pada http://www.g20.utoronto.ca/2008/2008declaration1115.html

Detik Finance, Rabu 15 Apr 2009, “ Kronologi dan Latar Belakang Krisis Finansial Global”, http://finance.detik.com/moneter/d-1115753/kronologi-dan-latar-belakang-krisis-finansialglobal 
Audriene, Dinda \& Agust Supriadi, CNN Indonesia, Rabu, 10 Agustus 2016, " Tranformasi Ekonomi Global di Mata Sri Mulyani Indrawati”, diakses pada http:// www.cnnindonesia.com/ekonomi/20160810120049-78-150406/tranformasi-ekonomiglobal-di-mata-sri-mulyani-indrawati/

G20 London Summit diakses pada http://www.g20.utoronto.ca/summits/2009london.html

G20 Research Group, "G20 Summit Commitments by Issue: 2008 to 2015", December 14, 2015, http://www.g20.utoronto.ca/compliance/ commitments.html\#2008

G20 members, diakses pada https://www.g20.org/about_g20/g20_members

G20 Leaders Summit : The Pittsburgh Summit diakses pada http:// www.g20.utoronto.ca/2009/2009communique0925.html 